\title{
A Korean perspective on megachurches as missional churches
}

\author{
Authors: \\ Cornelius J.P. Niemandt ${ }^{1}$ \\ Yongsoo Lee ${ }^{1}$ \\ Affiliations: \\ ${ }^{1}$ Department Science of \\ Religion and Missiology, \\ University of Pretoria, \\ South Africa \\ Correspondence to: \\ Nelus Niemandt \\ Email: \\ nelus.niemandt@up.ac.za \\ Postal address: \\ Private Bag X20, Hatfiled \\ 0028, South Africa \\ Dates: \\ Received: 08 Feb. 2015 \\ Accepted: 09 June 2015 \\ Published: 31 July 2015 \\ How to cite this article: \\ Niemandt, C.J.P. \& Lee, Y., \\ 2015, 'A Korean perspective \\ on megachurches as \\ missional churches', Verbum \\ et Ecclesia 36(1), Art. \#1421, \\ 8 pages. http://dx.doi. \\ org/10.4102/ve.v36i1.1421

\section{Copyright:} \\ (C) 2015. The Authors. \\ Licensee: AOSIS \\ OpenJournals. This work is \\ licensed under the Creative \\ Commons Attribution \\ License.
}

Read online:

Scan this $Q R$

code with your

smart phone or

mobile device

to read online.
Both the megachurch and the missional church are on-going global phenomena. Working from the premise that the church has to be missional, this article operates from a Korean perspective and researches whether a megachurch can be missional. The megachurch is not simply a very large church in terms of membership or the physical size of its building(s) - because of the influence of the interaction between socio-cultural, historical, and theological backgrounds, the megachurch has its own missiological and ecclesiological perspectives. The megachurch understands that the growth of an individual church implies the expansion of the kingdom of God, which means that the individual church has a responsibility to be both functionally and structurally sound, in order to ensure the efficient growth of the kingdom. This is an influential tendency that is found not only in larger size churches, but in all churches who are trying to achieve the quantitative growth of the church by way of evangelisation. The Korean megachurches, represented by the Poongsunghan Church, display these characteristics. The missional church is not simply a mission-driven church, sending many missionaries to other countries; the missional church believes that all churches are sent to the world by God, who wants to reconcile the whole universe with himself. The implication of this is that the church has to restore its missional essence in order to be able to participate in the mission of God. Thus, the missional church is a reforming movement that witnesses to God's rule by recovering its apostolic nature. The characteristics of this movement are clearly visible in one of the case studies - the Bundang Woori Church. The importance of the missional movement for Korean churches is emphasised.

Interdisciplinary and/or interdisciplinary implications: The research is a case study of Korean megachurches from a missional perspective. The research represents a critique of practises in Korean megachurches and a contrarian view of the mainline discourse in terms of the popularised view of Korean megachurches. The research may result in new insights in the missional possibilities open to megachurches.

\section{Introduction}

The word 'megachurch' refers to very large churches. According to Thumma and Travis (2007:xx), 'megachurch' generally refers to those churches which have more than 2000 people gathering for a Sunday service. In terms of this definition, the range of megachurches can be considerable.

If defining the missional church simply implied 'the church doing missionary work', then 'megachurches' can also be called missional churches, as the great number of members and the offerings of megachurches are very helpful where the performance of this generally recognised 'mission work' is concerned; in which the 'haves' support the 'have-nots' (Padilla 2010:70-71), both in physical and spiritual ways. The same is true, to some extent, if a missional church is simply defined as 'a church carrying out social service programmes'. In fact, if these were to be our definitions of 'missional church', then non-megachurches could almost not be considered they would be unable to 'catch up' with megachurches: because of their smaller congregations with less members, the social service programmes that they are able to provide are much less varied than those of megachurches. However, to use the words of Son (2012):

The mission that the missional church tries to carry out is not the one whereby the church in strong and powerful countries gives out something to the church in weak countries. (p. 45)

And the missional church cannot be simply defined as a church doing some social service work for society.

With all of the above as background, this research wants to answer the research question: 'Can a megachurch be missional?' It does so from within the premise that 'the church must be missional' 
(Guder 1998:102-109). The World Council of Churches states in the policy document The Church that the church is by its very nature missionary, and is called and sent to witness in its own life to that communion which God intends for all humanity and for all creation in the kingdom (World Council of Churches WCC - 2013:13). In the light of this, the research goals are: (1) properly situating the differing definitions and characteristics of a megachurch and a missional church, (2) figuring out how those definitions and characteristics are practised in both a Korean megachurch and a missional church and (3) comparing and criticising the megachurch's understanding of mission, and the church from the missional church's missiological and ecclesiological perspectives. The aim is to contribute towards the missional church discourse, especially in Korea.

\section{Megachurch}

Thumma (1996:427) describes the unique position of megachurches from a historical perspective, especially in terms of growth rate, building(s), and numerical size. The global influence of megachurches must also be noted, as these churches export their ideas and ecclesiologies. The explosive growth and growing influence is the result of a vast array of socio-cultural, historical, and theological factors. As urbanisation and market economy emerged, along with industrialisation, people got used to mega-sized buildings, masses of people, and consumerism. The megachurch follows in the footsteps of this particular kind of consumerism, with its scale of economy (Thumma \& Travis 2007:14).

The following factors also interacted or were mixed with the church growth theory, as well as the pragmatism of the new evangelism: (1) Competition, in terms of expansion, started among denominations together with their discovery of the New World, (2) a new appreciation for large-scale conversion, through the movements surrounding the Great Awakening and (3) the World Mission (Evangelisation) movement, with its emphasis on the Great Commission of Christ. This led, at least, to the idea that the growth of an individual church equals the expansion of the kingdom of God; therefore the church has to all means in order to guarantee growth.

In this research, the definition of a megachurch is no longer on the size of the church (i.e. with more than 2000 attendees), but more on the church as a social and religious tendency and/ or ethos that makes all megachurches (and potential or notyet-megachurches) concentrate on increasing numbers, size, influence (power), and the expansion of the territorial concept of the kingdom of God. This definition of the megachurch is connected to an ecclesio-centric understanding of mission (missiology), and to a functional and organisational (institutional) approach to the church (ecclesiology) and the way it views and does its missionary work (Shin 2012a:4).

\section{Missional church}

Theologically, the missional church is related to the missio Dei (i.e. the mission of God). Van Gelder and Zscheile (2011:32) state that mission precedes the church, and that mission must be understood as God's mission, where missionary activity is not so much the work of the church as simply the Church at work. They argue: 'The understanding of church as missionary by nature stems from realizing that God is missionary in God's very being' (Van Gelder \& Zscheile 2011:32). Since the idea or concept of the missio Dei was rediscovered at the Willingen mission conference in 1952, mission has been understood to be the essence of the church. The implication is that the church is no longer the subject of mission, but rather the instrument of the missionary God. The church is an identity in God's identity (Hastings 2012:loc.821-822). The church's true and authentic organising principle is mission (Hirsch 2006:82). Thus, all churches and their members must participate in the mission of God. Van Gelder and Zscheile (2011:4) unpack the idea of missional church and identify four themes:

- God is a missionary God who sends the church into the world.

- God's mission in the world is related to the reign (kingdom) of God.

- The missional church is an incarnational (versus an attractional) ministry sent to engage a postmodern, postChristendom globalized context.

- The internal life of the missional church focuses on every believer living as a disciple engaging in mission.

The social and cultural background of the present-day missional church is both post-Christendom and postmodern. In the present pluralistic and anti-authoritarian world the old way of Christian mission (i.e. 'Christendom mode'), which focused on attracting people to the church, no longer works, as the church becomes ever more marginalised. Today's world calls for 'incarnational mission', a mode of mission which focuses on going to people in their contexts and building relationships with them there; thus affording people a taste of the kingdom of God, rather than the church as institution (The Archbishop's Council 2004:xi). The church is understood as being a community of people discerning what God is actively doing in the world around them, and then participating in God's work. The focus is on the ordinary lives of the people of a local congregation through which the Spirit is shaping a new future (Roxburgh 2011:167). It is about engaging God in the community through his Word (Niemandt 2010:411).

The missional church finds the origin for this understanding in its historical background - the witnessing life of the disciples of the early church, who let people experience the eschatological kingdom of God through the process of joining the present kingdom of God. According to proponents of the missional church, the discipleship of the early church has to be restored by testifying to God's rule, in incarnational ways, through their everyday lives (i.e. with words and deeds that represent an ethical and/or holy life) as disciples of Christ Jesus (Roxburgh 2011:172).

In this research, missional church is defined as a movement towards the restoration of the missionary nature of the church, in the midst of the crises it is confronted with. 
This definition of the missional church is connected to a Theocentric understanding of mission (missiology), as well as to the theological discipline of understanding and defining the church as a Christian movement (Niemandt 2012:1), in this way restoring the apostolic nature of the church.

\section{Comparison and critiques of the 'megachurch', from the perspective of the missional church}

This research focuses on megachurches and missional churches from a Korean perspective, and illustrates the arguments by referring to two cases studies.

\section{A Korean megachurch}

The Poongsunghan Church is situated in Busan, the second largest city in South Korea, and has more than 6000 members. It has significant influence in Korea due to its dramatic growth and organisational system, called the 'Two Wings Nurturing System'. This system differs from the traditional church order by placing all church members, except the senior pastor, into small groups ('Open Cells'). These small groups are focused on evangelism. Poongsunghan Church organises an international conference every year (attended by more than 10000 delegates), with the aim of propagating this system throughout Korea. Poonsunghan Church can be described as a typical megachurch with its focus on growth, reliance on programmes, and the charismatic leadership of a senior pastor.

\section{A Korean missional church}

Bundang Woori Church was founded in the Bundang metropolitan area about 10 years ago. Since its inception, it has decided to rent a high school auditorium, rather than having its own building. Though it grew exponentially, quickly reaching about 20000 registered church members; the core of this church is a movement called the 'Sending 10000 Member Movement'. Since 2012, the church has started downsizing by sending their well-trained members to smaller and weaker churches in their vicinity.

\section{Critiques of the megachurch from the missional church's missiological viewpoint}

The ecclesiology of megachurches and missional churches differ: the former focuses on ecclesio-centric mission, while the latter focuses on Theocentric mission. In this research, the mission of megachurches is compared with Korean missional churches in terms of the following three characteristics of Theocentric mission (see Frost \& Hirsch 2013:277):

- Theocentric mission does not view the kingdom of God as a regional and/or territorial concept, but as God's rule. It changes the focus from a place to a person, and a new mission command is given to God's new people along with this change (Wells 2006:402-403)

- it is an incarnational mission, living as an alternative community in the world (Van Gelder \& Zscheile 2011:50)

- it concentrates on discipleship.
In the case study, Bundang Woori Church sees itself as a kingdom community, and it has been trying to fulfil the needs of their local community by running the 'Open Joseph's Store House' project from 2009, in which the church establishes multicultural family support centres, senior welfare centres, as well as rehabilitation centres for the disabled; separate from projects propagating the gospel by witness. Church members participate in the mission of God by serving the local society through their work in the different centres. Church members also volunteer in the 'Edu-Together' project - volunteer tutors are matched with poor students in Bundang. Through these services, the church aims to make tangible the present and eschatological rule of God in its particular context.

Poongsunghan Church differs from Bundang Woori Church. The church understands its mission as the propagation of its particular church system through the planting of new 'daughter churches', both within the country (e.g. Poongsunghan Church in Ilsan), and outside of the country (e.g. in China and India); based on the strength of the numerical growth of the mother church through the 'Two Wings Nurturing System'. The influence of the church on surrounding areas and countries, through the 'Two Wings International Conference', has resulted in a typical 'Christendom-mode' mission, which understands the kingdom of God as territorial expansion. Their emphasis on 'winning souls' already suggests something about the understanding of the idea of the kingdom of God.

Korean megachurches must be understood in terms of its evangelical roots. Bosch (1991:262) argues that the evangelism of evangelicals is affected by the Enlightenment, rather than directed by the New Testament. To them, salvation is a matter for individuals, which translates into letting individual non-believers listen to the gospel, persuading them to conversion by confronting them with the question: 'Are you saved?' The implication is that, even when large-scale crusades are held by evangelicals, the goal is still the salvation of the individual. This individualistic kind of evangelism can be described as reflecting the Enlightenment's vision of human beings, since it supports the idea and that human beings are autonomous decision makers, masters of their own fate and faith (Bosch 1991:267). Bosch (1991:144) argues that early Christians did not see salvation as something that happened to isolated individuals. The focus was to accompany individuals to move into the eschatological community of believers, which implies that the completion of the kingdom of God is given as a foretaste to the community of believers. Put differently, the church is a sign of the kingdom of God and of the proleptic manifestation of God's reign, both in what it is and what it does (Van Gelder 2000:99). For the early church, salvation thus meant moving into the kingdom community here and now, leaving the present world order behind. According to Guder (2000:loc.1439-1450), on account of their reductive soteriology, evangelicals have confined the Christian faith to an individual matter, and reduced it to 
something psychological. The result is that evangelicalism has not been able to grow out of an increasingly irrelevant 'religious ghetto', which looks to Christianity's geographical expansion through church growth by baptism rather than to God's continuing sovereign authority and activity over all things, with as goal the restoration of creation (Snyder 2001:146-147). Thus, evangelicals' focus in mission work is on the 'winning of souls' without any focus on social participation or community (Shin 2012b:7).

Bundang Woori Church focuses on discerning the movement of the Trinitarian God in their communities to practise an incarnational mission (see Moynagh \& Harrold 2012:loc.1610). As a result of this process of discernment, the church focuses on serving the youth and the dysfunctional families found in their local communities, with the aim of helping them to be restored holistically. The church concentrates on relationships rather than focusing on running growth-oriented programmes (Lee 2003:101-103). Managing a book café at the church, as well as hosting an annual banquet in the church's front yard for the community, exemplifies the church's efforts to be a fellowship-oriented church (Lee 2003:75-76). This relationship-centred ministry of the church led to the development of their indigenous, contextualised worship; as it was done in partnership with the new believers joining the community (Frost \& Hirsch 2013:35). They have a 'family blessing service' once a month, and the Sunday afternoon service is a modern-style service aimed at the community's youth.

The 'Two Wings Nurturing System' of the Poongsunghan Church is a combination of different church growth programmes, with a strong focus on numerical growth. Through the 'Open Cell', the first step of the system, the church goes out and gathers people. They treat people to a meal and give them gifts for 12 planned weeks, in order to build and strengthen relationships. This seems to be an incarnational act. However, as Frost and Hirsch (2013:65) point out, 'even though the program might be sound and biblical and is obviously very effective in its original context, it nevertheless smacks of something artificial', because building relationships is to them nothing but a means of bringing people into the church and attracting new members. The excessive confidence in the 'Two Wings Nurturing System' causes the church to ignore contextualisation. The system must be rigorously transplanted into each new church, without any contextualisation in terms of specific conditions (Kim 2005:61), or keeping in mind that the results cannot be guaranteed (Cho 2010). This is, to borrow Frost and Hirsch's (2013:109) expression, a typical 'one-size-fits-all approach'. The Poongsunghan Church, as a 'seeker' style megachurch, pursues the tailoring of their worship services to be able to attract seekers (people without any church affiliation) to the church building.

The 'attractional' and dualistic mission viewpoint of the megachurch can be critiqued from the missional church's incarnational perspective on the following grounds:
(1) inducing excessive competition, (2) being 'excarnational' (non-incarnational) and (3) practical atheism.

Padilla (2010:120) criticises the 'attractional' and dualistic mission of the church in that it sometimes creates a regrettable spirit of competition that is more related to the capitalistic system than to the Word of God, as it focuses on numerical growth. Under these conditions of keen competition, churches are easily lured into compromise their message, thus manipulating the hearers through pressure techniques and using statistics dishonestly (Padilla 2010:67).

As for 'excarnational', Frost and Hirsch (2013:35) say 'by anticipating that if they get their internal features right, people will flock to the services, the church betrays its belief in attractionalism'. Although the early church's practicing of its faith made them attractive to the society surrounding them, the present church is becoming more and more irrelevant to society by becoming self-centred, thinking that it could be attractive if its product (i.e. internal congregational life) is better (Chester \& Timmis 2011:loc.345).

In terms of practical atheism, the dualism of the megachurch's mission has over 1700 years created Christians that cannot relate their interior faith to their exterior practice; and this affects their ethics, their lifestyles, and their capacity to share their faith meaningfully with others (Frost \& Hirsch 2013:26). Consequently, according to a survey on the credibility of the Korean church - conducted by the Christian Ethics Movement Korea in 2011 - only 17.6\% of Koreans answered that they trusted Christianity. This indicates a continual decline when this percentage is compared to that of 2009 $(19.1 \%)$ and $2010(18.4 \%)$. This credibility gap that exists between the 'church world' and the 'real world' is what is described as the practical atheism of Christians (Frost \& Hirsch 2013:37).

All these imperfections of the megachurch's mission cause the church to fail its high calling to be the light and the salt of the world, as God's kingdom community that lives different from the world, yet in the world. As Niemandt (2012:4) said, only being incarnational decentres the church from a self-centred life and makes the church sensitive towards outsiders and strangers.

The cases studies made it clear that both Bundang Woori Church and Poongsunghan Church put a great deal of effort into raising disciples. Both churches have also been influenced by the discipleship training programme of the Sarang Church, of which the motto is: 'Awaken the laity'. But, although they focus on raising disciples under the influence of the same programme, due to their different understandings of what mission is, the characteristics of their discipleship programme (and therefore their results) are quite different. According to Hirsch (2006:122-126), there are two types of approaches to disciple making - the 'Hellenistic approach' and the 'Hebraic approach'. The 'Hellenistic approach' is based on the Hellenistic idea of knowledge. If 
people get the right ideas and information, they will change their behaviour. The problem is that information and new ideas in themselves do not change behaviour. On the other hand, the 'Hebraic approach' believes that education, in the context of life and for life, is needed in order to transform a person. This is the way that Jesus made disciples; for not only did he live with his disciples in their everyday contexts, but he also mentored them and trained them by his example.

Bundang Woori Church follows the Hebraic style of disciple making. At his sermon on 26 January 2014, pastor Chan-Soo Lee (the senior pastor of the church) said that he did not know where to go. Many other large churches in Korea misunderstood his pure intensions, after he had proclaimed and launched the 'Sending 10000 Members Movement', through which the church would send 10000 members to join and help the smaller and weaker churches in their vicinity within the next 10 years. The launching of this movement was the best way to participate in the mission of God, alongside other churches as one body of Christ, and through that being able to recover the good influence the church ought to have as the salt and light within Korean society. Thus he, as disciple of Jesus, controlled his desire to be a bigger church and obey the Holy Spirit. His hope, with the launching of the movement, was that all the members who chose to participate would struggle, make mistakes, and correct these mistakes together with him. According to the homepage of the church, a number of the church's members followed his lead, venturing out to neighbouring small churches, in the process also giving up all kinds of conveniences that they could have enjoyed as members of a large church. Instead, the participants in this movement learnt the value and impact of service and sacrifice, through their attendance of and service to the smaller surrounding churches.

In contrast, the Poongsunghan Church manages the 'World Vision Disciple School', which consists of three sessions: discipleship training, soldiership training, and reproduction training. To finish all three of these courses takes about a year, and, by passing all three courses, a new member of the church has been transformed into a reproductive leader of the Church. Their approach is thus system-centred, which also makes it close to the Hellenistic approach, which believes a person can be transformed through the gaining of knowledge (no matter how short the period of time). Although the Church does have the course trainees take part (and even lead) an 'Open Cell' meeting, in order to be trained in a practical way, the competitive nature of these meetings causes the focus to become the raising of disciples working within and for the Church; rather than disciples presenting the kingdom of God to the local community, through their involvement in all aspects of the community's everyday life.

According to Kwon (2014), the problem in the Korean church is that the church only focuses on raising church leaders to work for church growth programmes; thus ignoring Jesus' emphasis on a sacrificial life and the disciples' struggle to be holy in all aspects of everyday life, in the workplace, at home, and everywhere in between.

\section{Critiques of the megachurch from the missional church's ecclesiological viewpoint}

According to Van Gelder (2000:37), the ministry of the church flows from the church's nature; and the organisation of the church is designed to support the ministry of the church. This means that all the characteristics of the ministries and organisations of both the megachurch and missional church should be determined by the understanding of the nature of the church. And the nature of the church is centred on its apostolicity, which is 'missionary sentness' (Van Gelder 2000:125). For the church to be true church, it has to have the following attributes: apostolic oneness, apostolic holiness, and apostolic catholicity. In this research, the understanding of the megachurch regarding the church's nature, as well as the ministerial and organisational characteristics that flow from this idea of the church's nature, will be critiqued by making use of a comparison of a Korean megachurch and a Korean missional church; specifically in terms of apostolic oneness, holiness, and catholicity.

The Bundang Woori Church has always tried to be a familylike community. It has a descriptive motto - 'laughing together and crying together'. According to the church's homepage, this motto is constantly being fulfilled through a couple of the church's projects; for example, helping and participating in the funerals of people unknown to the church, as well as the 'Gleaning Offering' (a special offering to help church members who unexpectedly find themselves in financial crisis). Through these projects, Bundang Woori Church successfully demonstrates to Korean society that it is becoming more nuclearised and individualised, especially when compared to the church as a loving community. Simultaneously, the Bundang Woori Church is also carrying out the 'Sending 10000 Member Movement', which emphasises that all churches who confess Jesus as the Lord are one body, with its members collectively forming the body of Christ Jesus. Through this movement, the Bundang Woori Church send out members of the congregation to local churches, in order to avoid the phenomenon of 'horizontal migration' that is prevalent in Korea. They will serve their local community by participating in the mission of God, together with the weaker churches they were sent to, in the neighbourhood they find themselves in.

Poongsunghan Church understands the body of Christ to be the manifestation of spiritual gifts in small groups, rather than interdependence amongst all the members (Van Gelder 2000:110). According to the 'Two Wings Nurturing System', all members have to take part in a 'Gifts Discovery Seminar', and thereafter have to be allocated to various programmes to serve according to their spiritual talent (Kim 2005:247-248). Although this understanding of the body of Christ does help those who are talented to work more efficiently in the church programmes, it is a idea based on practicability, rather than the sacrificial love and fellowship of Christ. A senior pastor says 
the following about the strong focus small groups: 'if a church grows through running well-organized small groups, there will be no problem, even if the church grows very large' (Kim 2005:125). This understanding of the oneness of the church, however, is not to make God known to the world through a loving and sacrificing community, but more to make the church grow through organisational and functional unity.

Bundang Woori Church rents an auditorium from a high school and did not focus on owning its own building. This is not only because the Church tried to be considerate to the people coming to the church with wounded hearts from their building-focused Korean churches; but also because the church tried to avoid following the worldly order of consumerism, which attempts to attract more people through large and luxurious buildings (see the book of the senior pastor, Running to be something not belonging to the world: A diary on church planting of the Bundang Woori Church [Lee 2013]). The church is dispatching its well-trained members to the weaker churches in their neighbourhood in order to share the blessing it has been enjoying; in contrast to the world, where the rich become richer and the poor become poorer.

The church follows an apostolic holiness that is in contrast to the greediness of the world, by donating the Seo-Hyun Education Centre to the local community after 10 years of usage. Chan-Soo Lee - the senior pastor - stated in a sermon on 26 January 2014 that:

this is the shape of the church with which God is pleased and the way to restore the good influence of the Korean church that has waned through excessive competition for growth. (n.p.)

Poongsunghan Church, following the managerial methods of shopping malls, pursues optimisation of productivity and efficiency of the consumerist society in Korea. The church has huge buildings, which have various convenient facilities, in the suburbs of a densely populated area. It also has an effective pyramid-type organisational structure. There are 12 direct disciples (full-time ministers) called 'directors', working under the charismatic leadership of the senior pastor. Each director manages 12 super-cell leaders, whilst each supercell leader manages 4 other cell leaders under them. Through this structure, the management policy of the leader can be quickly spread throughout the whole structure. The church is given to dispensing rewards and punishment, as can be seen from e.g. the promotions of a cell leader to a super-cell leader when he or she reproduces four other cells. The cell leader is also rewarded with a special ring in a ceremony before the whole congregation. In terms of punishment the opposite is true - if a cell fails to reproduce within a year, it is dissolved and merged into other cells. The Poongsunghan Church, as a seeker-type megachurch, designs its worship for seeker's satisfaction.

Megachurches are not prepared to occupy the margins of their cultural environment. Instead, they are committed to impacting the culture by portraying Christianity as useful, relevant, and user-friendly (Tennent 2010:29); in spite of the fact that 'Christianity is the profoundest wound that can be inflicted upon a man, calculated on the most dreadful scale to collide with everything' (Kierkegaard 1944:258) with its holiness. Shin (2009:210-211) criticises the megachurch's failure in holiness because of its understanding of baptism. Being baptised means devoting oneself to Jesus Christ, entrusting oneself to the resurrected Lord, and submitting oneself to his rule and protection; instead of to the worldly order where Caesar rules (Küng 2007:292). However, the megachurches, although insisting that they baptise worldly entertainment, managerial, and psychological methods in order to serve the congregation well; neglect to cut out the worldly ethos of focusing on growth, more profit, and bigger power and influence. As Chester and Timmis (2011:loc.693694) put it, 'the missional church's missional cutting edge are not events that are like culture but a life and message that are unlike culture'.

According to the annual report of Statistics Korea (2013:27), regarding the number of divorces that occurred in Korea during 2012: '114,316 divorces occurred from 327,073 marriages'. The Bundang region had the third highest divorce rate among the Korean cities, due to a regional characteristic which is that the majority of the region's population is from the upper-middle class (Statistics Korea 2013:21). Bundang Woori Church has been devoted to the restoration of broken families by encountering and exposing the destructive powers and principalities of the region. Through the church's worship services, as well as its various ministries for the restoration of families, a number of broken and dysfunctional families have been helped to recover. As these restored Christian families share their lives in local community, the local people - especially a generation of young people from dysfunctional homes who need to experience Christian families in action before they become husbands, wives, and parents - are seeing Christian living and grace modelled (Chester \& Timmis 2011:loc.945-947).

Poongsunghan Church understands the power of encounter as a territorial expansion of the church. Thus, in order to have command of the region the church has to bind territorial evil spirits; firstly by performing 'Prayer Walks', going around where the 'Open Cell' meetings will gather for the first four weeks of meetings. This prayer walking hails from the influence of the concept of 'territorial spirits' and 'spiritual mapping', advocated by some scholars centred on Peter Wagner ideas, at the second Lausanne Conference held in the Philippines in 1989 (Lee 2013). On the church's homepage, the senior pastor says that more abundant fruits (i.e. the winning of souls) can be expected through 'Open Cell' meetings after prayer walking, because the territorial evil spirits are chained, as found in Joshua 6.

In terms of the Catholicity of the church, megachurches focus on the propagation of the gospel without bodily presence. Shin (2009) says:

the New Testament way of revelation is that a messenger reveals the truth through his bodily presence and way of life, as Jesus 
revealed God and the truth through His body (Jn 12:45). By being among and with them Jesus Christ convinced His disciples to confess: 'You are the Christ, the Son of the living God' (Mt 16:16). (pp. 277-284)

\section{Conclusion}

This research compared the megachurch's understanding of 'church' and 'mission' with that of the missional church on the basis of definitions and characteristics; and criticised the megachurch from the missional church's missiological and ecclesiological perspectives, with the purpose of seeking the answer to the question 'Can a megachurch be missional?'

In terms of a missiological perspective, missional churches and megachurches differ in their understanding of the kingdom of God, incarnational mission and discipleship. This difference derives from the missional church's basis in the mission of God, whilst the megachurch is rooted in the mission of the church. The mission of the missional church is to play a role as an eschatological kingdom community, letting the world experience God's rule, in advance, through their incarnational life and the practicing of radical discipleship. On the contrary, the mission of the megachurch, rooted in ecclesio-centric mission, makes Christianity an irrelevant religious group which focuses only on bringing more persons to the church by competitively running various programmes without social participation, and by training disciples as workers to carry out the programmes effectively; seeing the kingdom of God as the church's territorial expansion through quantitative growth of the local church.

From an ecclesiological perspective, the understanding of the nature of the church is based on the four attributes of the church, which are interrelated and affect each other. The interpretation of its apostolicity throughout history has had an especially great influence on the understandings of the concept 'church' to be found in the megachurch and missional church respectively. Whilst the missional church sees the apostolicity of the church as being sent by the Lord to the world to witness to God's truth through words and deeds, following the example of Jesus and the apostles; the megachurch sees it as attracting more people from the world into the institutional church, because the authority of the apostles was bestowed upon the institutional church. With this interpretation of the apostolicity, the megachurch believes that the one, holy, catholic church cannot be attained by a visible earthly church, as an assembly of individuals aggravates divisions of the church by pursuing the individual church's unlimited growth, and is thus compromised by the worldly order (culture) to accomplish that growth effectively and efficiently; rather than being united as the one and holy body of Christ Jesus, separated from the world to confront and disarm the fallen destructive powers and principalities in the area where it was sent, through the living of an incarnational lifestyle that transcends time and space.

The conclusion of these Korean cases studies is that the missional church is a reforming movement for the restoration of the apostolic essence of the church, by overcoming the characteristics of the megachurch. It emerged from a combination of socio-cultural, historical, and theological backgrounds. Therefore, any mega-trended and megaminded churches that have the tendencies associated with the megachurch cannot be missional. The critique on the megachurch is not that it has a large number of attendees; and to be a missional church does not simply mean changing the ministries and organisations of the megachurch. It can only be possible when the church and all its members participate in the mission of God, keeping the nature of the church in view. In this sense, a large church can still be missional; although it is more difficult than with a small church. However, a church that is not resisting the megachurch phenomenon can never be a missional church, regardless of its size. There are cases where Korean society rates the Korean church as both spiritually and morally bankrupt. A number of pastors see the slowdown or decline of the numerical growth of the church as a problem to be solved by employing various methodologies and are fiercely competing with each other to boost the numbers of their church's attendance. The missional church, with its missional ecclesiology, is finding the way forward for the Korean church; but not as a result of the slowdown of its numerical growth, but rather because they have realised that the church has lost its missional (apostolic) genius. In order to change a crisis into an opportunity, the Korean church has to participate in the missional church movement, shifting its focus from 'attracting events', to creating 'attractive communities' with marginal status.

\section{Acknowledgements Competing interests}

The authors declare that they have no financial or personal relationships which may have inappropriately influenced them in writing this article.

\section{Authors' contributions}

This research was part of research for a MA Theology in the Department Science of Religion and Missiology, University of Pretoria, by Y.L. (University of Pretoria) under the supervision of C.J.P.N. (University of Pretoria). C.J.P.N. was responsible for the project design, conseptualisation of key aspects of the research and supervision, and final compilation and editing of the research. Y.L. made conceptual contributions, researched the case studies, prepared and compiled the research, and was the researcher responsible for the implementation of the original research proposal and outworking of the project.

\section{References}

Bosch, D.J., 1991, Transforming mission, Orbis, New York.

Chester, T. \& Timmis, S., 2011, Everyday church: Mission by being good neighbours, IVP [Kindle Edition], Nottingham.

Cho, K.Y., 2010, 'Two Wings, Its beginning and end, a contradictory equation', viewed $21 \mathrm{Mar} 2014$, from http://craaha.com/web/gboard/main. php?act=view\&group no=16\&board_no=131\&main_no=732\&rtn_page $=/$

Frost, M. \& Hirsch, A., 2013, The shaping of things to come: Innovation and mission for the 21st-century church, Baker, Grand Rapids. 
Guder, D.L., 1998, Missional church: A vision for the sending of the church in North America, Eerdmans, Grand Rapids.

Guder, D.L., 2000, The continuing conversion of the Church, Eerdmans [Kindle Edition], Grand Rapids.

Hastings, R., 2012, Missional God, missional church: Hope for re-evangelizing the West, IVP Academic [Kindle Edition], Downers Grove.

Hirsch, A., 2006, The forgotten ways: Reactivating the missional church, Baker, Grand Rapids.

Kierkegaard, S., 1944, Kierkegaard's attack upon 'Christendom' 1854-1855, Princeton University Press, Princeton.

Kim, S.K., 2005, Healthy church soaring with two wings, NCD, Busan.

Küng, H., 2007, The church, Han-Dle, Seoul.

Kwon, D.W., 2014, 'Can an elaborate and intensive discipleship training guarantee to produce disciples?', viewed 12 May 2014, from http://ppss. kr/archives/20469

Lee, C.S., 2003, Running to be something not belonging to the world: A diary on church plating of the Bundang Woori Church, The Word of Life, Seoul.

Lee, I.G., 2013, 'Unmasking the Spiritual Mapping', viewed 18 September 2014, from http://m.dangdangnews.com/articleView.html?idxno=21484\&menu=

Moynagh, M. \& Harrold, P., 2012, Church for every context. An introduction to theology and practice, SCM Press [Kindle Edition], London.

Niemandt, C.J.P., 2010, 'Five years of missional church - Reflections on missional ecclesiology', Missionalia 38(3), 397-413.

Niemandt, C.J.P., 2012, 'Trends in missional ecclesiology', HTS Theological Studies 68(1), Art. \#1198, 9 pages. http://dx.doi.org/10.4102/hts.v68i1.1198

Padilla, C.R., 2010, Mission between the times: Essays on the kingdom, Langham, Carlisle.
Roxburgh, A.J., 2011, Missional: Joining God in the neighborhood, Baker [Kindle Edition], Grand Rapids.

Shin, K.E., 2009, A refutation of the megachurch, Jung Yeon, Seoul.

Shin, K.E., 2012a, 'Desire the expansion of the kingdom of God', viewed 19 March 2014, from http://www.newsnjoy.or.kr/news/articleView.html?idxno=191450

Shin, K.E., 2012b, 'Megachurches and the distorted enthusiasm of evangelicals', viewed 19 March 2014, from http://www.newsnjoy.or.kr/news/articleView. html?idxno=191630

Snyder, H.A., 2001, Models of the kingdom, Wipf \&Stock, Eugene.

Son, C.N., 2012, Vocation \& mission, Joy Mission, Seoul.

Statistics Korea, 2013, Statistics of marriage and divorce in 2012, KOSIS, Seoul.

Tennent, T.C., 2010, Invitation to world missions: A Trinitarian missiology for the twenty-first century, Kregel, Grand Rapids.

The Archbishop's council, 2004, Mission-shaped church, Church House, London.

The World Council of Churches, 2013, Resource book World Council of Churches 10th assembly, WCC, Geneva.

Thumma, S., 1996, 'The kingdom, the power, and the glory: Megachurches in modern American society', PhD dissertation, Dept. of Religion, Emory University.

Thumma, S. \& Travis, D., 2007, Beyond megachurch myths, Jossey-Bass, San Francisco. Van Gelder, C., 2000, The essence of the church, Baker, Grand Rapids.

Van Gelder, C. \& Zscheile, D.J., 2011, The missional church in perspective, Baker [Kindle Edition], Grand Rapids.

Wells, D.F., 2006, No place for the truth, or, whatever happened to evangelical theology? Revival and Reformation, Seoul. 